\title{
Giant ductal pseudoaneurysm in infancy: a lesson learnt the hard way
}

\author{
Maitri Chaudhuri, ${ }^{1}$ Shamanna Seshadri Iyengar, ${ }^{1}$ Subash Vidyashankar Chandra, ${ }^{1}$ \\ Devananda Shivanna
}

- Additional material is published online only. To view please visit the journal online (http://dx.doi.org/10.1136/ bcr-2017-223315).

${ }^{1}$ Department of Cardiology, Manipal Hospitals, Bangalore, India

${ }^{2}$ Department of Cardiothoracic Surgery, Manipal Hospitals, Bangalore, Karnataka

Correspondence to Dr Shamanna Seshadri lyengar ssiyengar1945@gmail.com

Accepted 7 December 2017
CrossMark

\begin{tabular}{|l|}
\hline To cite: Chaudhuri M, \\
Iyengar SS, Chandra SV, et al. \\
BMJ Case Rep Published \\
Online First: [please \\
include Day Month Year]. \\
doi:10.1136/bcr-2017- \\
223315 \\
\hline
\end{tabular}

\section{DESCRIPTION}

A 7-month-old girl, ex-preterm (26-weeker), $4.5 \mathrm{~kg}$, with $4 \mathrm{~mm}$ patent ductus arteriosus (PDA) underwent PDA device closure (Amplatzer duct occluder - ADO II $4 \times 6 \mathrm{~mm}$ ) elsewhere and was readmitted 4 days later with pericardial effusion. Needle pericardiocentesis drained $50 \mathrm{~mL}$ of haemorrhagic fluid. Septic screen was negative. Severe dyspnoea ensued 2 weeks later. Chest X-ray excluded lung pathology. Bedside echocardiogram showed PDA device in situ (online supplementary video 1), no residual ductus, vegetation or pericardial recollection, unobstructed flow in the pulmonary artery and descending aorta, normal pulmonary arterial pressures, and normal biventricular function. Curiously, a giant anechoic mass $(22 \times 25 \mathrm{~mm}$ ) (online supplementary video 2 ) was visualised posteroinferior to the device with its neck communicating with lesser curvature of the thoracic aorta at the level of origin of the left subclavian artery (figure $1 \mathrm{~A}, \mathrm{~B}$ ). Intra-aneurysmal thrombus or aortic dissection was absent. We diagnosed giant ductal pseudoaneurysm with possible left bronchial compression.

She underwent emergency surgical resection of pseudoaneurysm, retrieval of device, and

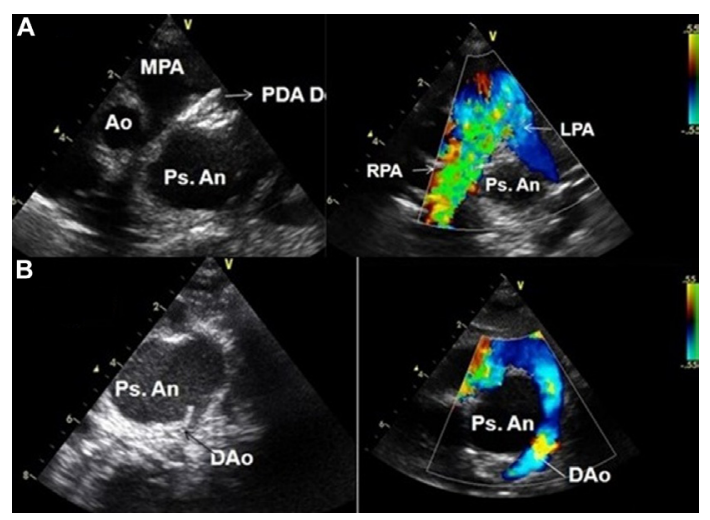

Figure 1 (A) Parasternal short-axis transthoracic twodimensional echocardiogram showing patent ductus arteriosus (PDA) device (PDA D, indicated by arrow) with giant pseudoaneurysm (Ps. An) posteroinferior to it. Ao, aortic valve; MPA, main pulmonary artery. Right hand panel shows the colour Doppler image of preserved pulmonary arterial flows (LPA, left pulmonary artery; RPA, right pulmonary artery) without any residual ductus with the pseudoaneurysm (Ps. An) sandwiched between the two. (B) Modified suprasternal echo-colour Doppler showing the location of pseudoaneurysm (Ps. An) inferior to transverse arch and medial to the descending aorta (DAo) without any evidence of coarctation of aorta.

\section{Patient's perspective}

When my preterm baby was diagnosed to have a hole in the heart called PDA, I was devastated. However, I was reassured that it may be closed even without surgery. But, when medicines did not close the PDA, I was advised regarding non-surgical closure with device. This did not turn out to be a great option as my child ultimately required a 6 hour massive surgery to correct the first procedure. I was told that this is a rarest of rare event but I hope it never happens to any baby again.

\section{Learning points}

- A pseudoaneurysm/false aneurysm develops when the vascular wall is injured and the blood is contained by surrounding structures.

- Trauma to patent ductus arteriosus (PDA) during PDA device closure must be avoided and the guidewires/device and others must be carefully manipulated.

- New-onset haemorrhagic pericardial effusion occurring post cardiac intervention is always a red flag. Serial bedside echocardiography is enough to evaluate any unusual clinical presentation. We re-emphasise that there is no 'routine intervention' in paediatric catheterisation laboratory.

reconstruction of pulmonary artery and aorta with homograft. Intraoperatively, perforation of proximal ductal wall by guidewire in the catheterisation laboratory was discovered. Fortunately, as the perforation leaked subacutely and the pseudoaneurysm was supported by the left pulmonary artery and left bronchus from above and below, respectively, it did not rupture.

This case highlights an uncommon sequel to a common paediatric intervention. New-onset haemorrhagic pericardial effusion is always a 'red flag', and serial, clinically focused echocardiography is required. To conclude, although PDA device closure has $93 \%-97 \%$ success rate, ${ }^{12}$ every intervention is still a challenge, and this is the first report of postdevice ductal pseudoaneurysm ${ }^{3}$ in infancy.

Contributors $M C$ took care of the patient and wrote the manuscript. SVC contributed to management plan and writing. SSI was involved in discussions and writing. DS was the operating surgeon. 
Competing interests None declared.

Patient consent Guardian consent obtained.

Provenance and peer review Not commissioned; externally peer reviewed.

(c) BMJ Publishing Group Ltd (unless otherwise stated in the text of the article) 2017. All rights reserved. No commercial use is permitted unless otherwise expressly granted.

\section{REFERENCES}

1 R. Yarrabolu T. Transcatheter closure of patent ductus arteriosus. Pediatrics \& Therapeutics 2012; S5.

2 Masura J, Tittel P, Gavora P, et al. Long-term outcome of transcatheter patent ductus arteriosus closure using Amplatzer duct occluders. Am Heart I 2006;151:e7-e10.

3 Lu H, Yan T, Wang J, et al. Successful stent for a pseudoaneurysm after the patent ductus arteriosus closure procedure. Interact Cardiovasc Thorac Surg 2013;17:1038-9.

Copyright 2017 BMJ Publishing Group. All rights reserved. For permission to reuse any of this content visit http://group.bmj.com/group/rights-licensing/permissions.

BMJ Case Report Fellows may re-use this article for personal use and teaching without any further permission.

Become a Fellow of BMJ Case Reports today and you can:

- Submit as many cases as you like

- Enjoy fast sympathetic peer review and rapid publication of accepted articles

- Access all the published articles

Re-use any of the published material for personal use and teaching without further permission

For information on Institutional Fellowships contact consortiasales@bmjgroup.com

Visit casereports.bmj.com for more articles like this and to become a Fellow 